\title{
Ideology, Realpolitik, and US Foreign Policy
}

\section{A Discussion of Frank P. Harvey's Explaining the Iraq War: Counterfactual Theory, Logic and Evidence}

Explaining the Iraq War: Counterfactual Theory, Logic and Evidence. By Frank P. Harvey. New York: Cambridge University Press, 2011. 360p. \$103.00 cloth, \$29.99 paper.

The Iraq War initiated by the Bush administration in 2003 was and perhaps continues to be an important episode in world politics, US politics, and the politics of the Middle East. The war also galvanized controversy among public intellectuals and broader publics, and generated strong opposition in many European and Middle Eastern countries. In Explaining the Iraq War, Frank P. Harvey offers an interesting analysis of the war and its causes, and does so in a way that raises broader questions about politics and about the scientific study of politics. We have thus invited a distinguished group of political scientists from a variety of subfields to review the book, both as an account of the Iraq War and as a contribution to political science more generally.-Jeffrey C. Isaac, Editor

\section{Adeed Dawisha}

doi:10.1017/S153759271300087X

Frank Harvey begins his provocative book by setting out the accepted narrative of the 2003 war on Iraq, that the decision to go to war was "a product of the political biases, misguided priorities, intentional deceptions and grand strategies of President George W. Bush and prominent 'neoconservatives,' 'unilateralists' and 'Vulcans' on his national security team" (p. 1). Harvey goes on to conceptualize this thesis as neoconism, whose central tenet is that a Bush administration dominated by powerful neoconservatives was a necessary condition for the Iraq War (p. 10; his emphasis). I doubt very much whether anyone who has attended academic conferences and meetings after 2003 would contest Harvey's assertion that this is a widely held view.

The advocates of neoconism go further. They use counterfactual analysis to emphasize the sole culpability of Bush and the neocons. What if $\mathrm{Al}$ Gore had won the hotly contested 2000 elections, they ask? If Bush and the neocons were so central in the decision to go to war, then the obvious conclusion is that a President Gore with starkly

Adeed Dawisha is Distinguished Professor of Political Science at Miami University of Ohio. different preferences and subject to the counsel of nonneocon advisors would have shied away from a war with Iraq. In Harvey's own words, "if neoconservative preferences in a Bush administration were a necessary condition for war, then a Gore presidency would have been a suffcient condition for peace" (p. 11). This counterfactual has been endorsed and enthusiastically advocated in scores of scholarly books and conference papers (pp. 11-13, esp. nn. 20-25).

Harvey disagrees, however, and he sets out to turn this counterfactual argument on its head. Utilizing some of the most innovative and rigorous counterfactual analysis that I have yet seen, he ends up providing "an explanation [for the $2003 \mathrm{war}$ ] that is much stronger than neoconism" (p. 271). The explanation starkly states that in all probability, Gore would not have acted differently from Bush, that he would have been compelled to follow the same path and go to war with Iraq (p. 280). Harvey does this by looking at a number of analytical categories that span Gore's personality and political outlook, the views of his potential political and security advisors, the existing organizational and bureaucratic environment, societal pressures and public opinion, global debates and maneuverings, and Saddam Hussein's machinations and miscalculations.

Harvey well knows that he has a controversial thesis, particularly in the liberally soaked world of academia. So 
he has taken great care in supporting his analysis with thick research. Now, I am not a specialist on U.S. foreign policy; my expertise lies in Middle East politics, and my research over the last decade or so has focused on Iraq. Harvey's analysis of Saddam's machinations and grand misperceptions (to which I shall return later) was of particular interest to me. Still, one does not have to be a specialist to appreciate the voluminous evidence amassed by the author to convince the reader of the high probability that a President Gore would have followed a similar policy track toward Iraq to the one pursued by President Bush.

In exploring Gore's own convictions (a crucial element of the analysis, since neoconism places so much emphasis on Bush's own beliefs), Harvey concludes that "by any measure, including conservative Republican standards, Gore was a foreign policy hawk" (p. 47). Here is presidential candidate Gore in April 2000: "[A]s long as Saddam Hussein stays in power there can be no comprehensive peace.... We have made it our policy to see Saddam Hussein gone" (p. 51). And two years later in a speech to the Council on Foreign Relations, Gore supported the occasional application of unilateralism when he said that the United States should tackle global challenges "with others, if possible; alone if we must" (p. 52). These statement are not two isolated examples; such hawkish views are repeated time and again in a large collection of statements and extracts from speeches put together by the author in two long appendices.

Harvey also convincingly shows that the potential members of Gore's national security team would hardly have modified the views of their boss. Again, two long appendices (pp. 109-25) demonstrate that this group believed that Saddam was an obvious menace to the United States and that his removal was a legitimate goal. Harvey rightly concludes that "there is very little that one can find in these speeches, editorials or scholarly articles (or any other work produced by these officials) that would produce a profile of an administration committed to pursuing a completely different path than the one Bush ... selected" (p. 108). And if in July 2002 it was Gore, not Bush, who went to the Senate asking for authorization "to use all necessary means to force Saddam's compliance," then the response of the senators would not have been any different from the one Bush received. After all, Democrats overwhelmingly backed the July 2002 resolution.

Of course, one reason for congressional support was the prevalent belief that Saddam was in possession of weapons of mass destruction (WMDs) — a belief neoconism attributes to the purposeful and perfidious efforts of administration officials to manipulate intelligence reports so that they fit in with the administration's predetermined goals. This was particularly the case with three intelligence estimates: operational linkage between Saddam and Al Qaeda, Saddam's attempt to acquire aluminum tubes for centrifuge enrichment, and his attempt to purchase uranium from Africa (p. 147). As we now know, these three estimates turned out to be baseless, and as such became the heart of the intellectual assault on Bush and the neocons. Yet Harvey remains unconvinced. He argues that these estimates were only a fraction of the hundreds of intelligence estimates produced in the United States, United Kingdom, United Nations, and European Union, almost all of which turned out to be seriously flawed, which was hardly surprising, given the departure of inspectors in 1998, lack of human intelligence on the ground in Iraq, and Saddam's purposeful ambiguity and deception (pp. 147-52). Left in the dark, Western analysts could only make prognostications based on data and evidence that was at least five years old. As late as March 6, 2003, Hans Blix, the Swedish head of the UN weapons inspection team, presented a report that included no fewer than 175 pages of "unresolved disarmament issues" related to Iraq's weapons programs (p. 152).

At this point in the book, readers are likely to ask the obvious question: What about the fictitious tale of Saddam acquiring uranium from Niger? As a reminder, President Bush declared in his 2003 State of the Union address that Saddam sought significant quantities of uranium from Africa, which turned out to be Niger. In February 2003, the CIA dispatched Ambassador Joe Wilson to verify the claim. After looking at uranium mines and interviewing a former prime minister, Wilson came back convinced that no such sale ever occurred. His report, however, was ignored, and this has been used by critics as the ultimate proof of the administration's perfidy - that Bush and the neocons suppressed the evidence because they were intent on waging war against Iraq. Harvey, however, counters by saying that Wilson's interview with one Niger official hardly constituted "evidence," and that Wilson's findings were basically opinions that at the time went very much against a much stronger and much more widespread suspicion that Saddam did possess WMDs. Harvey refers to many documents produced at the time in UN reports and by UK and U.S. intelligence agencies that cemented the suspicion that the Iraqis did possess WMDs (pp. 158-65).

As a researcher, I find Harvey's arguments, supported by the evidence he musters, to be compelling. But I do concede that this is not my area of specialty, and so I would rather defer to the opinions and comments of experts on national security and intelligence, and I am sure, given the provocative nature of this book, that they will not be lacking in numbers. But the next task that Harvey tackles does fall within my own area of expertise. Few will deny that much of the intelligence failure was due to the confusion caused by Saddam himself. One would think that since the case for war made by the United States and UK rested for the most part on Iraq's possession of WMDs, Saddam, knowing this to be false, would have opened up the country to UN inspectors, especially when an unambiguous deadline was set for compliance. That he did not is a mystery that Harvey tries to unravel. 
Relying on prison interviews with Saddam and former government officials, Harvey paints a picture of the Iraqi dictator as someone intent on practicing strategic ambigu$i t y$, hence the unwillingness to confirm the absence of WMDs. The reasons are spelled out by Saddam himself. He tells an interviewer that he had "to defend the Arab nation against the Persians and Israelis." He was convinced that if these two nemeses believed Iraq to be weak, they would attack, and it was "well known that the Israelis and Persians [had WMDs]" (p. 244). So as he embarked on destroying the weapons, he wiped out all information pertaining to their destruction, too. He also prevented his scientists from leaving Iraq, where without the constant presence of Saddam's thugs they would be able to speak more freely. The tragic irony about all this is that Iraq's travel embargo on scientists was seen in Washington as evidence of the existence and potency of Iraqi WMDs, and became a powerful element in the administration's rationale for invading Iraq.

Yet Saddam persisted in thinking that the United States would not go to war against Iraq. Even on the eve of the invasion, he still was dismissive of Washington's resolve to carry out its threat. According to Tariq Aziz, who for more than two decades was the manager of the country's foreign affairs, Saddam "thought that [the United States] would not fight a ground war because it would be too costly to the Americans" (p. 254). That this statement would come from a politically savvy senior member of the leadership begs the question of why Aziz would not offer a polite corrective, a contrary yet more realistic, assessment of U.S. capacity and its political environment. The answer, according to Harvey, is simple: Saddam thought that he knew all that was needed to know about the United States, and in fact admonished his chief advisors to leave the interpretation of American policy to him. Saddam would explain that America was such a complicated country that it needed the kind of alertness that was beyond the competence of his intelligence community. He would confidently declare in an interview that he needed neither information nor opinions on the United States, for after all, America was his "specialty" (p. 252).

In terms of the counterfactual "what if" analysis, it seems that whichever side one is on, the whole controversy would have been moot had Saddam allowed the UN inspectors a free rein in Iraq. After all, regardless of other arguments used by the Bush administration, the availability of WMDs to Saddam constituted the main pivot underpinning the rationale for going to war. There can be little doubt that an Iraq declared free of WMDs would not have been invaded. If Aziz or others in the pre-2003 Iraqi leadership would simply have asked for a discussion, or whispered a word of caution, or intimated their concern while still extolling the wisdom of their leader, then in all probability this episode in contemporary Iraqi and American history could have been avoided.
Megalomania is the inevitable offspring of tyranny, however. Aziz and the others surrounding Saddam knew well that any questioning of his opinions, no matter how obsequiously delivered, would not change the mind of the all-knowing tyrant; indeed, it could be the basis for dreadful incarceration, or worse. None of those supposedly "key" policymakers considered himself a "colleague" of Saddam, simply a subordinate who owed his privileged position to the president. No wonder then that Aziz, who was hardly a political slouch, would write an article about Hussein that read like a teenager's gushing love letter, eulogizing his beloved "hero-president" as "the struggler, the organizer, the thinker and the leader."

This culture of complete subordination was the result of many years of determined effort by Saddam's cronies to dig deep into Iraq's illustrious history and draw a continuous cultural and political time line, starting from the luminous civilizations of ancient Mesopotamia, running through the famed Baghdad-based Islamic empires, and ending with modern Iraq under Saddam. Immense resources were allocated for the endeavor, including the reconstruction of temples and arches of ancient Babylon, made with bricks inscribed with the name of Saddam Hussein. In Baghdad, a billboard of Saddam and the sixth century B.c. Nebuchadnezzar shaking hands depicted Saddam looking down on the legendary Babylonian king. ${ }^{2}$ By the early 1980s, it had become commonplace to see Saddam being mentioned not merely as one of the luminaries of Mesopotamian and Islamic history but as the decided overachiever among them. And in the two decades that followed, his minions made sure that newspapers, radio and television programs, books, school curricula, and artistic creations would reference this icon of the ages.

With such purposeful, constant, and coercive cultural subjugation, is it any surprise that no one, even those of the highest political status, would dare question the dominant historical figure that Saddam had become? If Saddam decreed that American motives, calculations, and policies were his specialty, then his declarations, no matter how questionable, would be met by the assembled higherups with a rapid nod of the head, by the prerequisite look of awe and admiration. And in the end, to this reviewer at least, it was this pervasive tyranny, built around the whims of one man, supported by a system of coercive cultural and political subordination, that is most culpable for the Iraq War.

Harvey may not go that far, but he does not doubt Saddam's crucial role in the war. Nor does he believe that the calculations of Iraq's tyrant would have changed in the face of a Gore rather than a Bush administration. This again adds to the author's rigorous counterfactual analyses and conclusions throughout the book that in all probability, Gore would have behaved no differently from Bush.

For this reviewer at least, the tightness of Harvey's argument, the extent of the evidence that he supplies, and the 
care and fastidiousness with which he presents his conclusions combine to produce a book that mercilessly assaults the notion that the responsibility for the 2003 war in Iraq falls squarely on the shoulders of Bush and the neocons, and on their misguided priorities and intentional deceptions (p. 1). In doing so, Harvey vigorously challenges an intellectual position that has become so enduring that it had achieved the status of a truth. And if this book does not, at a minimum, sow doubts in the minds of believers, then nothing will.

\section{Notes}

1 An article written by Tariq Aziz, then foreign minister of Iraq, for the Iraqi newspaper Al-Thawra on May 18, 1980, p. 1.

2 Eric Davis, Memories of State: Politics, History, and Collective Identity in Modern Iraq (Berkeley: University of California Press, 2005), p. 323, n. 53.

\section{John Ehrenberg \\ doi:10.1017/S1537592713000881}

Frank Harvey's work is less an attempt to explain the invasion and occupation of Iraq than an effort to challenge a central argument in most accounts of President George W. Bush's "war of choice." Harvey repeatedly says that he wants to refute the near-universal consensus that neoconservatives were the decisive factor in an administration that deliberately organized a push toward war. His secondary goal is to show that a counterfactual analysis and an argument about path-dependent momentum can provide a more credible account of the war than can "neoconist" orthodoxy.

Counterfactual analysis can be useful in reexamining one-time events that cannot be replicated, but one must be careful about setting up the argument. James Fearon's classic 1991 article suggests that Harvey has to make a choice between two-and only two-acceptable strategies. ${ }^{1}$ Either he can imagine what would have happened in a Bush administration that did not have any neoconservatives, or he can search for other actual cases that resemble the Bush administration in all significant respects except for the presence of neocons. In either case, Harvey would then have a relatively straightforward way of controlling for the one variable whose importance he wants to test.

Instead of pursuing this line of inquiry, though, Harvey takes us through an entirely different counterfactual: a Gore presidency. This decision has important consequences, for it takes his argument one significant step away from the immediate variable in question and asks his readers to imagine something dramatically different from a Bush presidency or a real-world alternative. Moving away from the neoconservatives as the independent variable weakens the power of the counterfactual by introducing other variables for which it is difficult to control. The author tries to examine many of them, but his effort is incomplete because it is no longer the neoconservatives for which he is controlling: it is the Bush presidency in general.

Harvey wants to counter the familiar argument that if Gore had won in 2000, there would have been no Iraq War. He does so by considering Gore's stated policy preferences and those of his principal foreign policy advisors; domestic political influences; organizational and bureaucratic forces (particularly the well-documented intelligence failures); the role of the media and American public opinion; the international environment; and Saddam Hussein's miscalculations about the regional situation and Washington's intentions. He argues that all of these forces would have pushed a President Al Gore in the direction that Bush ultimately took: an internationalist approach

John Ehrenberg is Chair and Senior Professor of Political Science at Long Island University. 
that was aimed at getting a United Nations Security Council resolution demanding the return of weapons inspectors to Iraq. Far from the unilateralist preemption that Bush's neoconservative advisors wanted, says Harvey, the administration pursued a conventional strategy that embraced containment, multilateralism, and diplomacy. The neoconservatives lost almost every important argument as Bush sided with Secretary of State Colin Powell and British Prime Minister Tony Blair. A President Gore, Harvey says, would have done substantially the same thing.

Harvey paints a picture of a conventional Bush foreign policy that was never driven by neoconservative unilateralists. Washington's support for a strong inspections regime was part of a broader aim to reinforce a $\mathrm{UN}$-centered policy organized around a demand for full and complete compliance with Security Council Resolution 1441. But things did not work out as Bush wanted. Once American troops were introduced to provide coercive muscle, things started to get out of hand. Path dependence created an irresistible momentum that led to a war Bush did not want. A combination of previous actions against Iraq stretching back three administrations, broad Democratic support for vigorous sanctions, an inflamed public traumatized by a terrorist attack, wide international support for a coercive inspection regime, faulty American intelligence, and Baghdad's recklessness fueled the momentum toward war. Bush's policy failed, but Harvey maintains that it was centered on getting the weapons inspectors back into Iraq and defusing the threat of Saddam's weapons of mass destruction (WMDs) without war. Given the erosion of the sanctions regime and the failure of containment, he argues, the same factors would have worked in a Gore administration.

The "Gore-War" counterfactual drives Harvey's claim that the neoconservatives were largely irrelevant as the Bush administration debated whether to seek congressional authorization and a Security Council resolutionboth of which were opposed by Vice President Dick Cheney, Deputy Secretary of Defense Paul Wolfowitz, and the "few" other neoconservatives who had the president's ear. Bush decided to go to Congress and to the Security Council, which Harvey takes as a sign that the neoconservatives were isolated while Bush built a multilateral approach to a problem that had bedeviled American foreign policy for years. But Harvey protests too much about the "neoconist" tendency to construct a simplified, conspiratorial theory of neoconservative leadership that denies the objective factors that were at work. His disclaimers notwithstanding, the real thrust of his book is to absolve not the neoconservatives but the Bush administration.

Explaining the Iraq War raises substantive issues that dovetail with Harvey's methodological approach. Just for the sake of argument, let us grant him his counterfactual that a President Gore would have done the same thing that Bush did. Does that mean that the neoconservatives played no important role in what actually happened? When my coeditors and I were assembling the important primary documents for The Iraq Papers (2010), we had to wrestle with many factors - chief among them the role of the neoconservatives. Like most neoconist approaches, and unlike the caricature presented by Harvey, we recognized that there were many different influences at work in the months and years leading up to the attack on Iraq. We considered — and included-broad discussions of American foreign policy, debates about containment, the question of oil, the "Israel lobby," Judith Miller's work at the New York Times, the international environment, and a host of other matters. Acknowledging that there were several forces at work does not mean that they were of equal weight. Harvey addresses this question, but the neoconist thesis does not stand or fall with a recognition that there were multiple impulses in play. Our careful reading of this historical record led us to include, and give much weight to, the role of neoconservatives in this particular administration at this particular moment in world history.

A worthy successor to organizations like the Committee on the Present Danger, the Project for the New American Century (PNAC) made its first public appearance with its "Statement of Principles" in 1997. Its neoconservative predecessors had repeatedly talked of imminent threat from a relentless Soviet foe that was intent on world conquest, issued dire warnings about the dangers of containment, and castigated Jimmy Carter for his naïve emphasis on negotiations, the Third World, and human rights. But the Project took shape in a drastically altered world, one shaped by the collapse of the Soviet Union and overwhelming American power. All that was lacking, it said, was the will to take advantage of a historic opportunity and reshape world politics in accordance with American interests and values. The PNAC announced its intention to argue for increased military spending and a more assertive foreign policy.

Six months later, the Project's statement of principles was followed by a letter to President Bill Clinton that specifically addressed the question of Iraq. It urged the president to abandon his strategy of containment and move toward a unilateral policy of regime change. Four and half years before September 11, 2001, and six years before the American invasion of Iraq, the Project for the New American Century had announced its views.

Harvey repeatedly accuses the neoconists of exaggerating the influence of the few neoconservatives who served in the Bush administration. But there were more than a few of them. Twenty-four people signed onto the PNAC's statement of principles. Eight of them went on to influential posts in the Bush administration, particularly in the Department of Defense and the office of the Vice President. They were joined by several other influential neoconservatives, like Douglas Feith and John Bolton, who were not signatories of the Project's statement. This is not 
a handful of marginalized advisors. This is a grouping of powerful and experienced people that was already on record about Iraq years before Bush became president.

The author takes Bush's decisions to seek congressional authorization and a Security Council resolution as a sign that the neoconservatives were defeated and marginalized. But he adopts a simplified and inaccurate picture of who they were, what they wanted, and what defeat means. Neoconservatism was never simply about unilateralism or preemption. Its core project was maintaining American military, economic, and diplomatic supremacy in what Charles Krauthammer called the "unipolar moment." Cheney, Donald Rumsfeld, Wolfowitz, and their colleagues certainly shared, and frequently expressed, a deep contempt for international law, the United Nations, Europe, human rights, multilateralism, and many other foundational pillars of traditional American foreign policy and the contemporary international environment. But this contempt was rooted in their desire to weaken the limits that the international community has erected to constrain the destructive potential of powerful states. Many of them were perfectly willing to live with the United Nations if it could be used to further American power without giving too much away. There might have been significant differences among them, and some of them were probably more willing than others to accept Bush's decisions about Congress and the Security Council. But in the end, it all worked out well. Saddam was to be the poster child for the "new American century," and the neoconservatives got the invasion they wanted.

Harvey characterizes "neoconism" as a conspiratorial view that features a handful of powerful advisors bamboozling a naive president, manipulating domestic opinion, and lying to dozens of experienced foreign leaders. But the historical record is quite clear. The administration threw a whole series of arguments up on the proverbial wall and waited to see which ones would stick. One of the reasons it was so difficult to have an honest debate about Iraq was that the administration constantly changed its arguments. This situation was messy and confusing, but it is also perfectly compatible with a picture of neoconservative preeminence. We summarized many of their initiatives in The Iraq Papers:

As Pentagon war planning became more serious during the spring and summer of 2002, the administration rallied a frightened population to its view of a changed U.S. role in the world. For the next year, new arguments about the Iraqi threat emerged as quickly as earlier claims were debunked. Saddam was actively cooperating with al Qaeda, or was quietly protecting it; he had weapons of mass destruction, or he was trying to get them; he was trying to build nuclear bombs, or he might be capable of doing so in the future; he had been deceiving UN weapons inspectors, or the inspectors were incompetent; he had denied his people the blessings of freedom, or his people were too cowed to know what was good for them; or, when all else failed, he was a mass murderer and a war criminal. ${ }^{2}$
Most accounts of the Iraq War are more sophisticated and nuanced than Harvey suggests. For our part, we never believed that neoconservatives forged some sort of grand conspiracy to manipulate the president, dissenting colleagues, popular opinion, and foreign leaders into war. History seldom works like that. On the contrary, they took advantage of emerging conditions, debated with their opponents, and provided very effective leadership. They thought that history had presented them with a unique opportunity to remake the world, and ultimate responsibility for the Iraq disaster falls squarely on their shoulders. There is plenty of room for others. At the end of the day, we are left with Bush, Powell, Blair, Condoleezza Rice, the neoconservatives, and their war. Harvey's flawed counterfactual and his selective reading of the historical record cannot change that. Nor should they.

\section{Notes}

1 Fearon 1991, 171.

2 Ehrenberg et al. 2010, 55.

\section{References}

Ehrenberg, John, and J. Patrice McSherry, José Ramón Sánchez, and Caroleen Marji Sayej, eds. 2010. The Iraq Papers. New York: Oxford University Press.

Fearon, James D. 1991. "Counterfactuals and Hypothesis Testing in Political Science.” World Politics 43(2): 169-95. 


\section{Bruce Gilley}

doi:10.1017/S1537592713000443

After President John F. Kennedy was assassinated, many commentators argued that the Vietnam War would have gone differently had he lived. Some imagined a whole new world in which the pressures that led the United States deeper into that conflict would have disappeared under JFK. ${ }^{1}$ In 2005, a groups of scholars and Kennedy-era policymakers held a conference to reconsider the "virtual JFK." While there was a lively debate, most of the policymakers and scholars present would not cede to the fantasy. On the key issue, they agreed that while Kennedy had decided in October 1963 to begin a withdrawal of American forces to be completed by the end of 1965 , intervening eventsincluding attacks on U.S. facilities in Vietnam, the 1964 presidential election, a collapsing South Vietnamese regime, and a growing hawkish camp within the administrationwould have reversed the decision had he lived. ${ }^{2}$

It is interesting to note that this "JFK war" scenario has been supported by both conservative historians like Diane $\mathrm{Kunz}^{3}$ and radical polemicists like Noam Chomsky. ${ }^{4}$ Both agree, along with others, that it was the liberal interventionist proclivities of a powerful United States that, rightly or wrongly, would have led JFK deeper into Vietnam. This is why James Blight and his colleagues, in their summary of the 2005 conference, call Vietnam "a Liberal's war." 5

After Al Gore lost the 2000 presidential election, a similar thing happened with respect to the Iraq War. Gore, it was argued by many respected scholars, ${ }^{6}$ would have acted differently than George W. Bush did, avoiding war and continuing the containment of the bothersome but not threatening Saddam Hussein regime. Like the JFK example, the peaceful version of the "virtual Gore" has been slow to come under scrutiny. Frank Harvey's greatest achievement in Explaining the Iraq War is to show how embarrassingly thin is the evidence for such a scenario. It is, as he writes, "a popular historical account that overlooks a substantial collection of historical facts and relevant causal variables that, when combined, represent a serious challenge to the core premises of accepted wisdom" (p. 3).

Laid out in meticulous fashion, Harvey's book provides the evidence that Gore was long a liberal hawk, especially on Iraq (Chap. 2); that his advisors and likely cabinet members were no less so (Chap. 3); that bipartisan congressional pressures to do something after 9/11 were immense (Chap. 4); that intelligence failures were not caused by Bush but by the anxieties that followed 9/11 (Chap. 5), as was public support for war against Iraq (Chap. 6); that UN weapons inspectors and key allies,

Bruce Gilley is Associate Professor of Political Science at Portland State University. including not just the UK but also Germany and France, agreed that Iraq had committed serial and serious breaches of United Nation containment provisions (Chap. 7); and that if there is a "first image" leadership story to be told about Iraq, it should center not on Bush but on Saddam, whose personalistic regime was deeply war prone (Chap. 8).

When we reduce the Iraq War to a childlike tale of a "bad Bush" or "bad neoconservatives," Harvey argues, we not only do a disservice to history but also lose the opportunity to address the factors that cause wars. Bush and his advisors appear in such a tale as magically able to convince Tony Blair, the U.S. Congress and public, and UN weapons inspectors that Saddam represented an unacceptable threat in the post-9/11 environment.

Harvey's work is both commendable and welcome, and should lead to much soul-searching among the academy, policymakers, and interested citizens, not to mention this country's two million or so Iraq War veterans who are often told that they fought because of a war-mongering president. By eliminating "Bush and the neocons" from the explanation of the Iraq War, Harvey re-centers attention on the factors that international relations theorists should have been focused on all along: U.S. unipolarity and the effects of the 9/11 attacks: "The two dominant forces that pushed the country down the path to war had nothing to do with individuals or ideology— $-9 / 11$ and the reality of US power were largely responsible" (p. 140). ${ }^{7}$

It is not just that without $9 / 11$, the anti-Saddam coalition within the Bush administration would have been whistling in the wind. Harvey's stronger claim is that assuming 9/11, even Gore would have moved aggressively to resolve the Iraq issue, given the risks of another attack and the dangers of a loss of U.S. deterrent credibility. Indeed, the proof of this claim is Bush himself, who came into office espousing a return to prudence and realism in American foreign policy. As Harvey shows, the same muscular interventionists who were waiting in the wings of the Bush administration to seize on 9/11 would have been waiting in the wings of a Gore administration-indeed, Bush emerges from these pages as something of a dove on Iraq compared to Gore's decade of bellicose rhetoric.

Harvey does not propose to review extant literature on the Iraq war, and so he can be forgiven for overlooking the fact that many scholars have in fact dismissed the "Bush and the neoconservatives" hypothesis to focus instead on the nature of the Saddam regime, ${ }^{8}$ U.S. unipolarity, ${ }^{9}$ and the effects of $9 / 11 .^{10}$ What Harvey's work achieves is an exhumation of the centrality of those factors through the novel looking glass of a virtual history experiment in a Gore presidency. In approaching the issue in this way, the author can show both why a virtual President Gore would have gone to war in Iraq and why the real President Bush did not go to war in Iran and North Korea. As he concludes in response to claims of determinism: "[M]ajor foreign policy decisions (especially decisions to go to war) 
made by leaders of powerful democracies are deterministic" (emphasis in original; p. 282).

The virtual history experiment also allows Harvey to examine causal mechanisms as well as causal factors (history being, if nothing else, strong on mechanisms). By showing how cabinet decision making, the intelligencegathering process, and diplomatic efforts would have played out much the same under Gore, he rejects the more nuanced "Gore peace" claims of those like James Blight and colleagues ${ }^{11}$ who argue that Gore would have been able to stall the slide to war because he was smarter. The reason, Harvey argues, is path dependence: Once "President Gore" had decided to pursue a coercive diplomatic solution to the Iraq crisis through the $\mathrm{UN}$ - a strategy he had long endorsed and which he would have driven more forcefully in cabinet deliberations than Bush did-there could have been no turning back if the strategy failed. The intelligence community, stung by its $9 / 11$ failure and searching for the most likely source of another one, would have produced largely the same dossiers in cooperation with key allies.

If any mechanism admits of counterfactual variation it is the diplomatic process. The key fact here, buried in the book but probably worth more attention, is that repeated French declarations in late 2002 and early 2003 that they would veto any war declaration fatally undermined the potency of the "enhanced inspections" process begun under Security Council Resolution 1441 in November 2002. Others have made the same point, ${ }^{12}$ but not with the same devastating clarity as Harvey, who, by eliminating the relevance of the "Bush factor," shines a sudden glare on Paris. As we have subsequently learned from Saddam's generals, the French attitude was "the single most important element" explaining why Saddam thumbed his nose at $1441 .^{13}$ If the post9/11 pressures on intelligence explain why Bush (and virtual Gore) could not have understood that Saddam was bluffing, the French behavior explains why Saddam could not have understood that the United States was not. As Harvey concludes: "France's decision to reject the military option increased the probability of war" (p. 231).

Bush, in other words, fought another "Liberal's war" in Iraq whose groundwork had been laid by the rise of muscular Wilsonianism in the unipolar Clinton era and whose near inevitability arose from the pathologies of Saddam and the changed national security atmosphere globally after 9/11. That may explain why President Barack Obama has continued most of the Bush foreign policy agenda, including a Lyndon Johnson-like escalation in Afghanistan. In retrospect, the United States may have been fortunate to have had a Republican president in Bush, who could easily revert to realist premises on Iraq once Saddam was overthrown. Only a unified Western alliance could have reduced the probability and consequences of the Iraq War-but then again, perhaps this is an unlikely counterfactual in light of post-World War II French foreign policy.
As with the "JFK war" hypothesis, the "Gore war" hypothesis is not a partisan claim. Many supporters and opponents alike of the Iraq War agree that Gore would have invaded, differing only on whether that would have been a bad or good thing. Rather, it is a bipartisan challenge to the widespread myth that American liberalism is essentially pacifist; it is not. Whether you think that has made the world a better or worse place is another matter.

Finally, on a lighter note, two men can take comfort from Harvey's analysis: Ralph Nader, whose 2000 presidential candidacy split the left-of-center vote, and Elian Gonzalez, now 18, the Cuban boy whose repatriation to Cuba by the Clinton administration in 2000 alienated Latino voters in the state of Florida. Even if they tipped the election, they did not tip the war, however.

Airport bookshops may thrive on contingent accounts of history-how Irish monks saved Western civilization or how Chinese sailors ignited the European Renaissance. But like them, the theory that George W. Bush caused the Iraq War represents an astonishing failure to show that changing one variable would make all other variables irrelevant. Harvey reminds us to take history, and politics that makes it, more seriously.

\section{Notes}

1 Jones 2003; Newman 1997.

2 Blight, Lang, and Welch 2009, 34-49.

3 Kunz 1997.

4 Chomsky 1993, Chaps. 5 and 6.

5 Blight, Lang, and Welch 2009, 32.

6 Ritchie and Rogers 2007.

7 See also Harvey 2004.

8 Woods, Lacey, and Murray 2006.

9 Miller 2010; Mowle and Sacko 2007.

10 Smith 2005; Tunç 2005.

11 Blight, Lang, and Welch 2009, Epilogue.

12 Clarke 2004; Malone 2006.

13 Woods 2006, 28.

\section{References}

Blight, James, Janet Lang, and David Welch. 2009.

Vietnam If Kennedy Had Lived: Virtual JFK. Lanham, MD.: Rowman \& Littlefield.

Chomsky, Noam. 1993. Rethinking Camelot: JFK, the Vietnam War, and U.S. Political Culture. Boston: South End.

Clarke, Michael. 2004. "The Diplomacy That Led to War in Iraq.” In The Conflict in Iraq 2003, ed. Paul Cornish. New York: Palgrave Macmillan.

Harvey, Frank P. 2004. "Addicted to Security: Globalized Terrorism and the Inevitability of American Unilateralism." International Journal 59(1): 27-57. 
Jones, Howard. 2003. Death of a Generation: How the Assassinations of Diem and JFK Prolonged the Vietnam War. New York: Oxford University Press.

Kunz, Diane. 1997. "Camelot Continued: What If John F Kennedy Had Lived?” In Virtual History: Alternatives and Counterfactuals, ed. Niall Ferguson. New York: Basic Books.

Malone, David. 2006. The International Struggle over Iraq: Politics in the UN Security Council 1980-2005. New York: Oxford University Press.

Miller, Benjamin. 2010. "Explaining Changes in U.S. Grand Strategy: 9/11, the Rise of Offensive Liberalism, and the War in Iraq." Security Studies 19(1): 26-65.

Mowle, Thomas S., and David H. Sacko. 2007. The Unipolar World: An Unbalanced Future. New York: Palgrave Macmillan.

Newman, John. 1997. "The Kennedy-Johnson Transition: The Case for Policy Reversal." In Vietnam: The Early Decisions, ed. L. C. Gardner and T. Gittinger. Austin: University of Texas Press.

Ritchie, Nick and Paul Rogers. 2007. The Political Road to War with Iraq: Bush, 9/11 and the Drive to Overthrow Saddam. New York: Routledge.

Smith, Philip. 2005. Why War? The Cultural Logic of Iraq, the Gulf War, and Suez. Chicago: University of Chicago Press.

Tunç, Hakan. 2005. "What Was It All About After All? The Causes of the Iraq War." Contemporary Security Policy 26(2): 335-55.

Woods, Kevin M. 2006. Iraqi Perspectives Project: A View of Operation Iraqi Freedom from Saddam's Senior Leadership. United States Joint Forces Command, Joint Center for Operational Analysis. Available at http:// purl.access.gpo.gov/GPO/LPS68139.

Woods, Kevin, James Lacey, and Williamson Murray. 2006. "Saddam's Delusions: The View From the Inside." Foreign Affairs 85(3): 1-13.

\section{Stephen M. Walt \\ doi:10.1017/S1537592713001138}

Frank P. Harvey's latest book offers a convoluted counterfactual analysis of the US decision to invade Iraq in 2003. Its primary purpose would seem to be the exoneration of the neoconservatives who conceived the idea of overthrowing Saddam Hussein and helped convince George W. Bush to implement that idea in the wake of September 11.

In particular, the book is an assault on what Harvey calls "neoconism," which he defines as "all first image (leadership) explanations that highlight any (or all) of the following ideologies as the main cause of the warneoconservatism, unilateralism, hegemonic realism, democratic realism, democratic imperialism, democratic globalism, Wilsonian or Hamiltonian revivalism, or economic nationalism" (p. 2). This is quite a list, but Harvey's definition of neoconism also includes any theory of the war "that blames Bush himself for being influenced by these powerful ideologues ... or any related explanation that relies on Bush's idiosyncratic beliefs, religious values, or decisionmaking style" (p. 2). In other words, if you think President Bush and the neoconservatives had a lot to do with the Iraq War, then you are guilty of neoconism.

In contrast to the neoconist critics, Harvey sees the attack on Iraq as a rational response to the strategic circumstances that the United States faced after 2001. He makes this case by invoking a broad counterfactual: Had Al Gore become president in 2000, a host of factors supposedly unrelated to those discussed by neoconist intellectuals would have led the United States to invade Iraq anyway. His main evidence is the fact that many Democrats-including Gore himselfmade statements in 2002 and 2003 that evinced concern about the dangers posed by Saddam Hussein and in the end supported Bush's decision to invade.

Harvey also tries to debunk the charge that the Bush administration mishandled or misrepresented the pre-war intelligence in order to convince the American people and key allies to support the war. In particular, he argues that many foreign intelligence services also thought Iraq had WMD. He also suggests that a Gore administration would have been more popular overseas than the Bush administration was, and thus in a better position to obtain Security Council approval for the war.

In this interpretation, the neoconservatives inside and outside the Bush administration bear little responsibility for the debacle; the Iraq War would have happened even if Paul Wolfowitz, Douglas Feith, Scooter Libby, and others had never held high office and if outsiders like William

Stephen M. Walt is the Robert and Renee Belfer Professsor of International Affairs at the Kennedy School of Government at Harvard University. 
Kristol, Robert Kagan, Charles Krauthammer, and others had not devoted years to making the case for an invasion.

Harvey's book is extensively documented, and he presents an exhaustive- one might even say exhausting combination of argument and evidence to support his view. But his interpretation of that evidence is unconvincing because 1) he misrepresents the views he is challenging, and 2) he fails to grasp the key role that the neoconservatives played in causing the war. Unfortunately for him, no amount of counterfactual speculation can erase their central role.

\section{Misrepresenting the Case for Neoconism}

Regarding the first problem, I shall focus on the example with which I am most familiar. In Chapter 8 of The Israel Lobby and U.S. Foreign Policy (2007), John Mearsheimer and I argued that "the driving force behind the Iraq war was a small band of neoconservatives" and we showed that the Bush administration's campaign to sell the war was supported by many of the key organizations and individuals in the broader Israel lobby. Our account would seem to be a textbook example of what Harvey calls neoconism, except that he falsely implies that we portray these groups as solely responsible for the war. In his words:

\footnotetext{
Oddly enough, neoconism has also been embraced by wellrespected international relations scholars who would otherwise downplay the role of idiosyncratic or domestic factors when explaining decisions to go to war. Perhaps the most notable example is Mearsheimer and Walt 2007. Apparently, despite their intellectual legacy extolling the explanatory relevance of structural factors (balance of power and state self-interest) these scholars are now prepared to discount system variables in favor of assigning significant causal weight to leadership and ideology-in this case, assigning significant influence to a few neocon leaders and a powerful domestic Israel lobby to explain the 2003 Iraq War. U.S. self-interest post-9/11 security threats associated with WMD proliferation, and other realist, state-centric interest were irrelevant in this case. (p. 3, n. 9, emphasis added)
}

There are two problems here. First, whether the story Mearsheimer and I tell about the lobby is at odds with realist theory is beside the point, as no social science theory explains every case and the Iraq War might be an exception. The only pertinent question is whether the core "domestic factors" we identify-the neoconservatives and other groups in the Israel lobby_-played the role we ascribe to them in this particular case.

Second, we did not say the strategic factors Harvey points to were irrelevant. On the contrary, we began our account of the Iraq War by noting that "the United States was the world's most powerful country" and pointed out that the "rapid ouster of the Taliban in the immediate aftermath of 9/11 reinforced an image of military invincibility and made it harder for skeptics on Iraq to convince others that going to war was unnecessary and unwise." ${ }^{1}$ We also underscored the key role of the 9/11 attacks, which convinced many American leaders "that the United States could not allow even remote dangers to grow in an era where terrorists might acquire WMD." 2 We described the United States as "simultaneously powerful, confident of its military prowess, and deeply worried about its own security - a dangerous combination" and said these various elements formed the "strategic context in which the decision for war was made." ${ }^{3}$ Each of these factors, in short, was clearly relevant in this case.

Yet we also emphasized that there was "another variable in the equation," and that "the war would almost certainly not have happened had it been absent." That factor was the Israel lobby, "and especially a group of neoconservative policymakers and pundits who had been pushing the United States to attack Iraq since well before 9/11." ${ }^{4}$ We recognized that "pressure from Israel and the lobby was not the only factor" behind the decision to attack, however, and that "had circumstances been different, they would not have been able to get the United States to go to war." 5 In our view, "the lobby's actions were a necessary but not sufficient condition for war." 6

Thus, Harvey's claim that, for us, "US self-interest, post9/11 security threats associated with WMD proliferation and other realist, state-centric self-interests were irrelevant" is false (p. 2 n. 9). In short, one can appreciate the critical role the neoconservatives played while recognizing that other factors facilitated their campaign for war.

\section{What Does Harvey's Evidence Really Show?}

To understand the neoconservatives' role, several key facts must be kept in mind. First, the neoconservatives invented the idea of invading Iraq and toppling Saddam. Together with groups such as the American Israel Public Affairs Committee (AIPAC), they were the only important actors pressuring Congress and the executive branch to support Iraqi exile groups, impose tougher sanctions on Baghdad and, if necessary, use force to overthrow Saddam. The State Department and the Pentagon weren't pushing for war and neither was the oil industry. Not surprisingly, therefore, President Clinton rejected the neocons' calls for military action and only reluctantly agreed to the AIPAC-sponsored Iraq Liberation Act in 1998. US military leaders remained unenthusiastic even after 9/11, and Secretary of Defense Donald Rumsfeld was furious when Army Chief of Staff Eric Shinseki told a Congressional committee that occupying Iraq would be a difficult task requiring several hundred thousand US troops. America's intelligence agencies did not favor war either, and the Bush administration had to go to great lengths to distort the existing intelligence to make war seem necessary. Indeed, top administration officials told a number of blatant untruths in the run-up to the war. ${ }^{7}$

Were it not for the neocons, in short, the idea of attacking Iraq would not have been on the table in the first place and the United States would have focused solely on Al Qaeda after 9/11, as it should have. It is worth remembering that Deputy Secretary of Defense Paul Wolfowitz 
advised Bush to invade Iraq a mere four days after 9/11, even though there was no evidence that Saddam had anything to do with the attacks. Bush rejected Wolfowitz's advice and went after the Taliban and Al Qaeda instead, but shortly thereafter he ordered the military to begin contingency planning for invading Iraq. As neoconservative writer Robert Kagan later commented, September 11 was "the turning point," and the neocons' success in persuading Bush to attack Iraq was due to the fact that they had a "ready-made approach" at precisely the moment when the administration was searching for some way to respond to an unprecedented disaster. ${ }^{8}$

A proper understanding of the neoconservatives' role places Harvey's counterfactual argument-and especially his evidence of bipartisan support for the war-in a different light. He is correct that many Democrats and liberal interventionists began talking about the threat from Iraq in the aftermath of $9 / 11$, and that many of them ultimately supported the war. But their testimony was not independent of the political context in which they were operating, and the neoconservatives both inside and outside the Bush administration were working overtime to shape that context. Bush's popularity had soared after $9 / 11$ and the ouster of the Taliban in the fall of 2001, making it increasingly difficult for Democrats to question the case for war against Iraq. And once Bush had embraced the neoconservatives' idea of "regional transformation" and begun to sell the war in earnest-an effort that involved falsely linking Saddam Hussein to Al Qaeda and assorted other deceptions-it was hardly surprising that prominent Democrats went along.

Of course, one cannot prove that Al Gore would not have followed a similar course had he faced the same strategic and domestic circumstances Bush did. Had a Gore administration ignored the same warnings that Bush \& Co. received about an upcoming Al Qaeda operation and thus failed to prevent 9/11, and had the United States then conducted a swift and successful assault against $\mathrm{Al}$ Qaeda's Taliban hosts, Gore might also have been deluded into believing that invading Iraq would deliver quick and far-reaching benefits. And had Gore faced a crescendo of pressure from neoconservatives and influential pro-Israel organizations like AIPAC, he might have ultimately decided to respond as Bush did. But this counterfactual in no way absolves the neoconservatives or the lobby from responsibility for the war; it merely suggests that their influence did not depend on whether Bush or Gore was in the White House.

The bottom line here is straightforward: Although the neoconservatives were not solely responsible for the decision to invade Iraq, they still deserve much of the blame. To be sure, the war would probably not have occurred if the 9/11 attacks had been thwarted, or had the initial campaign in Afghanistan been more difficult. By the same token, the war would never have occurred had the neo- conservatives not dreamt up the idea in the late 1990s and promoted it relentlessly for years. And when the stars lined up for them after 9/11, they got the war they had long desired. Thomas Friedman of the New York Times hit the nail on the head when he told an interviewer in 2003 that Iraq "was the war the neoconservatives wanted . . . the war the neoconservatives marketed .... I could give you the names of 25 people ... whom, if you exiled them to a desert island a year and half ago, the Iraq War would not have happened" (Ari Shavit, "White Man's Burden," Häaretz, 4 May 2003.)

To sum up: It was a combination of the neoconservatives' active promotion of the war, the support from other key groups in the Israel lobby, and a particular set of international and domestic circumstances that ultimately led the United States to make the fateful and foolish decision to attack Iraq. Harvey goes to great lengths to interpret things otherwise, and to this end he constructs an intriguing counterfactual narrative. But the facts speak for themselves.

\section{Notes}

1 Mearsheimer and Walt 2007, 229-30.

2 Ibid., 230.

3 Ibid.

4 Ibid.

5 Ibid., 233.

6 Ibid., 253.

7 Mearsheimer 2011, 49-55.

8 Packer 2005, 38.

\section{References}

Mearsheimer, John J. 2011. Why Leaders Lie: The Truth about Lying in International Politics. Oxford: Oxford University Press.

Mearsheimer, John J. and Stephen M. Walt. 2007. The Israel Lobby and U.S. Foreign Policy. New York: Farrar, Straus \& Giroux.

Packer, George. 2005. The Assassin's Gate: America in Iraq. New York: Farrar, Straus \& Giroux. 


\section{Elizabeth Saunders}

doi:10.1017/S1537592713000431

Frank Harvey has written a provocative and interesting book that admirably questions the conventional wisdom that $\mathrm{Al}$ Gore would not have initiated the Iraq War. His arguments raise often unacknowledged and untested assumptions about the counterfactual alternative of a Gore foreign policy after $9 / 11$.

While there is much to admire about the book, in this brief commentary I focus on one aspect of the counterfactual of the Iraq confrontation under a potential Gore presidency that Harvey does not address in detail but that deserves more attention: the nature of the war the United States might have fought in Iraq had Gore been elected, and the implications of Gore's potential strategy for the overall decision to fight in Iraq. Given Harvey's aim to challenge the prevailing few that Gore would not have attacked Iraq, his analysis primarily concerns whether Gore would have initiated the war. He makes the intriguing argument that Gore would have pushed for a multilateral inspection regime, which, in turn, would have set the United States on a path to war similar to that which unfolded under President George W. Bush.

The initiation of the war is only one aspect of the Iraq counterfactual, however, and cannot be separated from the conduct of the war itself. The nature of the intervention strategy a president contemplates is deeply intertwined with the decision to intervene in the first place, because he (or she) will view the decision to initiate a conflict through the prism of his (or her) preferred strategy. In the extreme, the options will narrow to a choice between the president's favored strategy or choosing not to intervene. Thus, the way the Bush administration prepared for and conducted the war was bound up with the decision to go to war in Iraq. Similarly, considering the question of how Gore might have prosecuted the war also affects our consideration of the counterfactual question of whether Gore would have initiated the war at all.

Among other features, Harvey's arguments highlight structural pressures that would likely have been the same in President Gore's world, a useful corrective to knee-jerk assumptions that events would have unfolded differently under a Gore administration. His discussion of individual leaders and Gore's views focuses on key similarities between Bush and the hawkish Gore (along with his running mate, Joseph Lieberman, and many of his advisers). But although Harvey argues that his "conclusions reveal serious deficiencies with first-image (leadership) theories of US foreign policy" (p. 286), Harvey glosses over some key differences between Gore and Bush that have important implications

Elizabeth Saunders is Assistant Professor of Political Science and International Affairs at George Washington University. for the Iraq counterfactual. A recent wave of research in international relations has placed renewed emphasis on the role of leaders. This research differentiates among leaders along key dimensions, such as past experience, beliefs, threat perceptions, and other politically relevant attributes, and suggests that it is possible to distinguish leaders systematically beyond simple hawk/dove or even unilateral/ multilateral preferences. ${ }^{1}$

One dimension that is relevant to the Iraq counterfactual concerns how leaders perceive and prepare to address threats. As I have discussed in detail elsewhere, presidents differ systematically in how they perceive threats, leading to differences in the intervention strategies they favor for addressing those threats. If presidents believe that the way other states are organized internally is the source of their threatening behavior-in the case of Iraq, a belief that the nature of the Iraqi regime led it to be potentially aggressive - then they are more likely to endorse an intervention strategy that will transform the target state's domestic institutions. Nation building would fall under the category of a transformative intervention. Alternatively, if leaders believe that any state can behave aggressively regardless of its institutions, they will be more likely to back a more limited intervention strategy, which might include removing the leadership of the target state but would not necessarily transform its institutions. ${ }^{2}$

Leaders' threat perceptions also have consequences for the capabilities available to presidents when they confront decisions to intervene. Presidents who arrive in office believing that threats arise internally are likely to make "policy investments" in capabilities that would bolster their ability to conduct transformative interventions. In contrast, those who do not see internal institutions as the ultimate source of threats are less likely to invest in transformative capabilities. These investments affect preparedness for different types of intervention and can constrain options when decisions arise, since leaders have effectively stacked the deck in favor of certain strategies. Even if they try to shift strategy, presidents may find themselves hampered by a lack of preparation that stems from their previous choices. Preparedness, in turn, affects the likelihood of initiating an intervention because it shapes estimates of costs and the probability of success for different intervention strategies. Thus, leaders' threat perceptions and their corresponding responses to those threats can shape war planning, rendering strategy inseparable from decisions to initiate war.

How did Bush and Gore compare in terms of their views on threats and strategies to respond to those threats? One crucial difference concerned nation building. Gore was a strong believer in nation building, whereas Bush came to office with a hearty disdain for it. During the first presidential debate in 2000, for example, Bush asserted that he and Gore had a "disagreement about the use of troops. He believes in nation building. I would be very 
careful about using our troops as nation builders. I believe the role of the military is to fight and win war and therefore prevent war from happening in the first place." ${ }^{3}$ In the second debate, when asked whether he would support a "civil force" to undertake nation building, Bush responded, "I think what we need to do is convince people who live in the lands they live in to build the nations. ... I mean, we're going to have kind of a nation building core from America? Absolutely not." He also argued that "our troops ought to be used to help overthrow the dictator when it's in our best interests. But in [the Somalia] case it was a nation-building exercise, and same with Haiti. I wouldn't have supported either." ${ }^{4}$ Bush thus drew a contrast between overthrowing dictators and nation building, suggesting that it was possible to do one without the other.

In contrast, Gore consistently defended nation building, both during the 2000 campaign and in the run-up to the Iraq War. In the second debate, Gore stated that he did not agree with Bush's position. Acknowledging that "this idea of nation building is kind of a pejorative phrase," Gore went on to give a strong defense of American nationbuilding efforts in the wake of World War II, noting that the effort was "economic . . . but it was also military." He argued that "having troops there" gave recovering countries "confidence," while civil administrators helped with rebuilding. ${ }^{5}$

In his speeches during the run-up to the Iraq Warincluding two speeches Harvey emphasizes in support of the argument that Gore would have initiated the warGore repeatedly highlighted the importance of postwar planning and of nation building, again explicitly endorsing the involvement of the United States in such endeavors. In his February 2002 speech to the Council on Foreign Relations, for example, Gore argued that a "final reckoning" with Iraq "should be on the table," but that "finishing it on our terms means more than a change of regime in Iraq" and must include "a workable plan for preventing the disintegration of Iraq into chaos." He also argued that "it isn't enough to destroy what is evil, and then seek to leave by the nearest door. We must make the commitment to work with those whom we have rescued until they can stand on their own feet." 6

In his September 2002 speech to the Commonwealth Club of California, Gore included a section on the "Dangers of Abandoning Iraq," arguing that "if we quickly succeed in a war against the weakened and depleted fourth rate military of Iraq ... the resulting chaos could easily pose a far greater danger to the United States than we presently face from Saddam [Hussein]." He criticized Secretary of Defense Donald Rumsfeld for dismissing questions about "restabilizing Iraq ... in the aftermath of the invasion," and quoted Bush's 2000 debate assertion that he would "absolutely not" support a separate nationbuilding capability. Drawing an explicit contrast with Bush,
Gore argued that "the events of the last 85 years provide ample evidence that our approach to winning the peace that follows war is almost as important as winning the war itself." He went on to discuss the virtues of "enlightened nation building" and the perils of leaving the field too early, specifically criticizing the Bush administration for failing to follow through after its intervention in Afghanistan. Finally, he urged Congress to "establish now what the administration's thinking is regarding the aftermath of a US attack for the purpose of regime change," and called for a congressional resolution requiring "commitments from the President that action in Iraq will not be permitted to distract from continuing and improving work to reconstruct Afghanistan, and that the United States will commit to stay the course for the reconstruction of Iraq."

The difference between the Gore and Bush stances on nation building has important implications for the way we set up the counterfactual of a Gore administration confronting Iraq because strategy and war planning constrain the options that presidents consider. Arguably, the relevant decision Gore faced was between intervening with a plan for a potentially lengthy postwar period and not intervening at all. For Bush, in contrast, the choice was between what he thought would be a limited intervention and no intervention.

Consider first the case of Bush, simpler because we have concrete information about how his views affected planning and available capabilities for the Iraq War. ${ }^{8}$ Bush's anti-nation-building stance set the tone for his administration: When he arrived in office, he appointed advisers like Rumsfeld and Condoleezza Rice, who also disdained nation building, and took bureaucratic measures to undo some of the Clinton administration's emphasis on it. These measures reduced material, bureaucratic, and intellectual capabilities for nation building, with important consequences for the way the war unfolded.

At the decision stage, Bush's opposition to nation building meant that he preferred a more limited intervention strategy, with the aim of removing Saddam and the top layer of leadership, but without a serious commitment to rebuilding the country. A nation-building intervention was explicitly taken off the table, as illustrated by the welldocumented lack of postwar planning. The initial U.S. strategy was one of "decapitation": As Rice later put it, the "concept was that we would defeat the army, but the institutions would hold, everything from ministries to police forces.... You would be able to bring new leadership but we were going to keep the body in place."9 Of course, U.S. policy later shifted to encompass rebuilding Iraqi institutions from the ground up, but it is important to recall that such an effort was not part of the initial strategy. ${ }^{10}$ Even the decisions concerning de-Baathification and disbanding the Iraqi army were not part of the initial plan. When the United States shifted in a more transformative direction in the wake of the power vacuum and the 
emerging insurgency, the lack of preparation for a nationbuilding intervention caught up with the administration. Military strategy is difficult to shift on short notice, and presidents must live with the policy investments (or lack of investments) they make at the outset of their administrations. Even if we stipulate that Bush's views changed after 9/11, his initial opposition to nation building had important consequences for the United States and Iraq as the war unfolded.

In the case of Gore, Harvey alludes to the nature of a potential Gore war only in passing. At the very end of the book, for example, he notes that Gore "would probably have recommended a much larger troop deployment, in line with General Anthony Zinni's plan under the Clinton administration," perhaps in the 400,000 range. Harvey argues that this larger deployment would have given Gore more confidence and that he would have been reluctant to maintain such a large deployment during a prolonged period of inspections, so that "Gore would have been more, not less inclined to accept the risks of war" (p. 305).

In the spirit of evaluating the counterfactual of a Gore presidency, however, it seems important to consider the implications of his explicit and consistent emphasis on nation building for his consideration of a war in Iraq. This emphasis suggests that he would plausibly have insisted on a plan for the postwar phase, leading to a choice between a potentially protracted war and no war at all. It is difficult to know how Gore would have evaluated the trade-off between a full-scale nation-building intervention in Iraq and staying out, but assessing that counterfactual would require information beyond the hawkish views that Harvey highlights.

Some aspects of a Gore assessment would likely flow from his views about the origin of threats and how intervention should be undertaken. One would expect that a President Gore would have continued the Clinton administration's efforts to institutionalize capabilities and lessons from the nation-building interventions of the 1990s. Those interventions were by no means entirely (or even mostly) successful, and my purpose here is not to suggest that Gore would have been right to emphasize nation building or that a Gore-initiated war in Iraq would have avoided the problems the United States confronted once the war began. ${ }^{11}$ To be sure, even a hypothetical Gore intervention with more investment in nation-building capabilities might well have struggled in Iraq. But this possibility, in turn, might have informed Gore's decision to intervene at all. He might have examined the trade-off between a decision not to intervene and the full-scale, transformative intervention he believed was required to secure Iraq, and concluded that the potential cost of intervening was too high or the probability of success was too low.

Had he decided that the costs were prohibitive or the chances of success (defined on his terms) were too low, could
Gore have stayed out of Iraq? Harvey suggests that the political costs of starting down the path of multilateral, intrusive inspections and subsequently backing down would have been too high for any president-particularly a Democrat-in the wake of $9 / 11$. But scholarship on public opinion and war has long emphasized that the public knows little about foreign policy and takes its cues on foreign policy from elites. ${ }^{12}$ The Bush administration made a major effort to garner the support of other elites on Iraq and to suppress elite criticism. The lack of criticism (and, in many cases, overt support) from Democratic members of Congress may have reflected Democratic caution about opposing a popular president in the wake of 9/11 once he put Iraq firmly on the agenda, but it does not necessarily imply that the Democrats themselves put such a high priority on attacking Iraq. Furthermore, recent scholarship has suggested that democratic publics may not punish leaders for backing down in crises, contrary to earlier arguments about "audience costs." ${ }^{13}$ As one study found, punishment is especially unlikely when the president explains why backing down was the right course. ${ }^{14}$ One could imagine that a politically savvy president who wanted to maintain the inspection regime in Iraq without resorting to war could have marshaled arguments, backed by an elite coalition, that would have kept public opinion largely quiescent on this issue.

Explaining the Iraq War is helpful in reminding us that counterfactual claims must be subjected to rigorous theoretical and empirical testing, and Harvey highlights oftenignored structural factors that would not likely have been different under a Gore administration. But it is important to consider not only whether Gore would have intervened but also how. After decades of ignoring the role of leaders, international relations scholarship has gotten much better at identifying how individuals affect key foreign policy and international political outcomes. In the case of the Iraq War, there is evidence that Bush's beliefs and decisions did influence the course of events in Iraq-not only the decision to intervene but also the choice of intervention strategy—suggesting that a President Gore might have chosen differently. This provocative book reminds us that despite their differences, presidents are constrained by international and domestic factors largely beyond their control. But individual leaders can have a profound impact on the ways in which states wage war, well beyond the moment the first shots are fired.

\section{Notes}

1 A partial list includes Byman and Pollack 2001; Chiozza and Goemans 2011; Colgan 2013; Goemans 2000; Horowitz et al. 2005; Rosen 2005; Saunders 2011.

2 The distinction between transformative and nontransformative interventions is fleshed out in more detail in Saunders 2011. 
3 First Gore-Bush Presidential Debate, Boston, October 3, 2000, http://www.presidency.ucsb.edu/ws/ index.php?pid=29418.

4 Second Gore-Bush Presidential Debate, WinstonSalem, NC, October 11, 2000, http://www.presidency. ucsb.edu/ws/index.php?pid=29419.

5 Second Gore-Bush Presidential Debate.

6 Gore 2002a.

7 Gore 2002b.

8 See the discussion in Saunders 2011, 196-211.

9 Quoted in Gordon and Trainor 2006, 142.

10 On this "nontransformative" initial approach to Iraq, see Saunders 2011, 203-11.

11 For an analysis of whether an alternative strategy might have worked in Iraq, see Byman 2008.

12 Berinsky 2009; Zaller 1992.

13 Downes and Sechser 2012; Snyder and Borghard 2011; Trachtenberg 2012.

14 Levendusky and Horowitz 2012.

\section{References}

Berinsky, Adam J. 2009. In Time of War: Understanding American Public Opinion from World War II to Iraq. Chicago: University of Chicago Press.

Byman, Daniel. 2008. "An Autopsy of the Iraq Debacle: Policy Failure or Bridge Too Far?” Security Studies 17(4): 599-643.

Byman, Daniel and Kenneth Pollack. 2001. "Let Us Now Praise Great Men: Bringing the Statesman Back In.” International Security 25(4): 107-46.

Chiozza, Giacomo and H. E. Goemans. 2011. Leaders and International Conflict. New York: Cambridge University Press.

Colgan, Jeff D. 2013. Petro-Aggression: When Oil Causes War. New York: Cambridge University Press.

Downes, Alexander B., and Todd S. Sechser. 2012. "The Illusion of Democratic Credibility." International Organization 66(3): 457-89.
Goemans, H. E. 2000. War and Punishment: The Causes of War Termination and the First World War. Princeton: Princeton University Press.

Gordon, Michael R., and Bernard E. Trainor. 2006. Cobra II: The Inside Story of the Invasion and Occupation of Iraq. New York: Pantheon Books.

Gore, Al. 2002a. "A Commentary on the War Against Terror: Our Larger Tasks.” Remarks to the Council on Foreign Relations, Washington, DC, February 12. Available at http://www.cfr.org/terrorism/ commentary-war-against-terror-our-larger-tasks/ p4343.

—. 2002b. "Iraq and the War on Terrorism." Remarks to the Commonwealth Club of California, San Francisco, September 23. Available at http://www. gwu.edu/ action/2004/gore/gore092302sp.html.

Horowitz, Michael, Rose McDermott, and Allan C. Stam. 2005. "Leader Age, Regime Type, and Violent International Relations." Journal of Conflict Resolution 49(5): 661-85.

Levendusky, Matthew S., and Michael C. Horowitz. 2012. "When Backing Down Is the Right Decision: Partisanship, New Information, and Audience Costs." Journal of Politics 74(2): 323-38.

Rosen, Stephen Peter. 2005. War and Human Nature. Princeton: Princeton University Press.

Saunders, Elizabeth N. 2011. Leaders at War: How Presidents Shape Military Interventions. Ithaca, NY: Cornell University Press.

Snyder, Jack, and Erica D. Borghard. 2011. "The Cost of Empty Threats: A Penny, Not a Pound." American Political Science Review 105(3): 437-56.

Trachtenberg, Marc. 2012. "Audience Costs: An Historical Analysis." Security Studies 21(1): 3-42.

Zaller, John. 1992. The Nature and Origins of Mass Opinion. Cambridge: Cambridge University Press. 